\title{
Gene expression, sperm viability, and queen (Apis mellifera) loss following pesticide exposure under laboratory and field conditions
}

\author{
Veeranan Chaimanee $^{1}$, Jeffery S. Pettis ${ }^{2,3}$ \\ ${ }^{1}$ Department of Agro-Industrial Biotechnology, Maejo University Phrae Campus, Phrae, Rong Kwang, Thailand \\ ${ }^{2}$ Bee Research Laboratory, USDA-ARS, Beltsville, MD, USA \\ ${ }^{3}$ Pettis and Assoc. LLC, Salisbury, MD, USA
}

Received 30 August 2018 - Revised 7 February 2019 - Accepted 19 March 2019

\begin{abstract}
Honey bee (Apis mellifera ) queens are failing, and this may be due in part to widespread miticide use by beekeepers. The ectoparasitic mite, Varroa destructor, is a major pest of honeybees and synthetic insecticides are often used to control Varroa. Amitraz is widely used by beekeepers worldwide. Amitraz is thought to be of low toxicity to bees, but applying high doses can cause negative effects. Here, we demonstrate a sublethal dose of amitraz can affect the detoxification, cyclic adenosine monophosphate (cAMP)-dependent protein kinase, immunity, antioxidant capacity, and development of honeybee queens when queens were exposed to amitraz ( $2.5 \mathrm{ppm})$ under laboratory conditions. Downregulation of genes related to detoxification enzymes, cAMP-dependent protein kinase, immunity, antioxidant enzymes, and development was observed. Sublethal doses of amitraz had no effects on the viability of spermatozoa stored in spermathecae of queen when treated topically in the laboratory. Lastly, we treated colonies with three formulations of amitraz and followed queens in these colonies for 3 months to explore queen loss and/or other adverse effects of miticide treatment. Queen loss averaged about 30\% over all treatment groups including untreated control colonies and no reduction in sperm viability was seen with amitraz treatments when queens remaining after 3 months were dissected. This research demonstrates that chemical exposure can affect some aspects of the queen immune system but sperm viability and queen longevity over 3 months were unaffected by colony level amitraz treatments under real-world conditions in honey bee colonies.
\end{abstract}

\section{Apis mellifera / queens / sperm viability / amitraz / gene expression / field conditions}

\section{INTRODUCTION}

The honeybee, Apis mellifera, is an economically important managed pollinator of crops worldwide (Klein et al. 2007). The decline of honeybee populations raises concern worldwide. Numerous factors such as pathogens, parasitic mites, nutrition limitation, and xenobiotic exposures may contribute these declines (Evans and Schwarz 2011; Cornman et al.

Corresponding author: V. Chaimanee, chveeranan@gmail.com

Manuscript editor: Michelle L Flenniken
2012). Poor queens and queen loss are often cited by beekeepers as leading to colony losses and pesticides may play a role in queen problems (Williams et al. 2015; Pettis et al. 2016; Straub et al. 2016). Miticides are used by beekeepers to control the parasitic mite Varroa destructor. The ectoparasitic mite, $V$. destructor, is a major threat to A. mellifera across the USA and around the world. Varroa is often controlled by synthetic miticide treatments such as amitraz (Apivar®), tau-fluvalinate (Apistan $囚)$ and coumaphos (CheckMite+®). Additionally, natural products are used for mite control including thymol (e.g., ApiGuard®) and formic acid (e.g., MiteAway QuickStrips®). 
Of the synthetic miticides, amitraz is widely used worldwide because of resistance by the mites to other compounds (Elzen et al. 1998; Elzen and Westervelt 2002; Pettis 2004). Amitraz is a formamidine and acts on the central nervous system of ectoparasites by interacting with octopamine receptors which causes lethal and sublethal effects (Evans and Gee 1980). The low doses of pesticides can sublethally affect honeybee physiology, development, longevity, immunology and behavior (Desneux et al. 2007). Amitraz does not accumulate in honeybee colonies but rather rapidly metabolizes to other forms, 2,4-dimethylphenylformamind (DMF) and $N$-(2,4-dimethylphenyl)- $N^{\prime}$ methylformamidine (DPMF) (Korta et al. 2001). These amitraz metabolites have been detected in bees and wax (Mullin et al. 2010). Amitraz exposure did not have negative effects on learning and memory of honeybees when applied under worse case scenarios (Rix and Cutler 2017). In addition, amitraz had no negative effects on immunity of honeybee workers (Garrido et al. 2013). Although amitraz is thought to be relatively non-toxic to bees, it has the potential to synergize with other insecticides (Johnson et al. 2013; Rinkevich et al. 2015). Amitraz continues to be widely used to control Varroa in honeybee colonies. While amitraz has been an effective mite control, higher doses have been applied by beekeepers as some suspect resistance is developing and these higher doses may be toxic to honeybees (Dahlgren et al. 2012). Most studies of amitraz effects on honeybees have focused on workers. However, the honeybee queen's health is critical to colony performance, productivity and longevity (Rangel et al. 2013). Queen failure has been proposed to be a cause of honeybee colony losses (vanEngelsdorp et al. 2013; Antúnez et al. 2017). Exposure to pesticides is considered one of the factors leading to queen failure (Sandrock et al. 2014; Dively et al. 2015). Only a few studies have reported on the effects of amitraz on honeybee queens even though it is the most widely used miticide in bee colonies (Vandenberg and Shimanuki 1990; Dahlgren et al. 2012).

Although amitraz has not been demonstrated to adversely affect honeybee physiology and behavior, it might act at the molecular level, potentially altering detoxification pathways, immune response and the expression of antioxidative enzymes and developmental genes. Cytochrome P450 monooxygenase (P450s), glutathione transferase (GSTs), and carboxylesterases (COEs) are the major enzyme superfamilies responsible for the metabolism or detoxification of xenobiotics and pesticides ( $\mathrm{Li}$ et al. 2007). Several studies have demonstrated that these enzyme superfamilies are involved in the metabolism of chemicals in honeybees (Johnson et al. 2006, 2012; Mao et al. 2011). The members of CYP6 and CYP9 families are generally associated with insecticide detoxification in honeybees and other insects (Berenbaum 2002; Ranson et al. 2002; Feyereisen 2005). Other studies showed that CYP4G11 and CYP6AS14 are active in the neonicotinoid insecticide imidacloprid detoxification of honeybees (Hu et al. 2017). However, imidacloprid and the organophosphate acaricide coumaphos caused the suppression of CYP306A1, CYP4G11, and CYP6AS14 expression in honeybee queens (Chaimanee et al. 2016). GSTs also play an important role in detoxification of endogenous and xenobiotic compounds and also protection cell from oxidative stress (Enayati et al. 2005; Claudianos et al. 2006). GSTs are involved in insecticide mechanism in other insect species including mosquito (Enayati et al. 2005; Ketterman et al. 2011; Lumjuan et al. 2011). Recently, GSTs have been associated with mechanism against oxidative stress in the Asian honeybee, Apis cerana cerana (Yan et al. 2013). Besides the detoxification pathways, the immune system and antioxidant enzymes are also involved in the defense mechanism of xenobiotics (Corona and Robinson 2006; Antúnez et al. 2009). However, immunosuppression in honeybee larvae and queens after pesticide exposure has been reported (Di Prisco et al. 2013; Chaimanee et al. 2016; Brandt et al. 2017).

This study investigated the sublethal effects of amitraz on sperm viability in honeybee queens by analyzing the viability of spermatozoa in the spermatheca of honeybee queens after amitraz exposure under laboratory conditions. The expression of genes related to detoxification enzymes, cyclic adenosine monophosphate (cAMP)-dependent protein kinase, immunity, and antioxidant enzymes in amitraz-exposed queens was also determined. Lastly, we field tested the effects of colonylevel amitraz treatment in commercial beehives on queen survival and sperm viability. 


\section{MATERIALS AND METHODS}

\subsection{Sublethal exposure to amitraz under laboratory conditions}

\subsubsection{Honeybee queens}

Mated queens (Apis mellifera ligustica) used in the laboratory exposure experiments were obtained from a single commercial queen breeder in Hawaii, USA. They were shipped within 2 days in wooden Benton cages with five to six attendant bees to the Bee Research Laboratory in Beltsville, MD, USA in September 2013.

\subsubsection{Effect of sublethal dose of amitraz on sperm viability}

Analytical grade chemicals amitraz (purity 98.2\%) was purchased from Sigma-Aldrich, Co. (St. Louis, MO). Methanol was chosen as a solvent because of its low toxicity to bee. Amitraz was dissolved in methanol and diluted to concentrations of $2.5,12.5,25$, and $50 \mathrm{ppm}$ which represented as sublethal doses of amitraz $\left(\mathrm{LD}_{50}=\right.$ 750 ppm) (Mullin et al. 2010). Four amitraz treatment groups were established; each group consisted of six queens, and methanol was assigned as a negative control group. Two microliters of each concentration was applied topically on the abdomen of queens using a repeating dispenser (Eppendorf Repeater ${ }^{\circledR}$ plus Manual Dispenser). Queens were then transferred back to wooden Benton cages with attendant bees and kept at $30 \pm 2{ }^{\circ} \mathrm{C}$. Mortality was recorded daily. Seven days post-treatment, live queens were dissected and the spermathecae removed and placed in a buffer solution (Moritz 1984) for determining the spermatozoa viability rate.

\subsubsection{Sperm viability}

The semen in the spermatheca was released by puncturing the spermatheca with a needle. Then, the semen was mixed in $200 \mu \mathrm{l}$ buffer and gently agitated and the spermathecal remains were removed. The spermatozoa viability rate was determined by staining the semen with $1 \mu \mathrm{l} \mathrm{SYBR}-14$ dye and $8 \mu$ l propidium iodide (Live/Dead Sperm
Viability Kit, L-7011, Molecular Probes) following the manufacturer's protocol. Live (green) and dead (red) cells were counted using a fluorescent light source with an isothiocyanate (FITC) filter (Axioskop 2 plus, Carl Zeiss) after the diluted semen was incubated in the dark for $15 \mathrm{~min}$ at room temperature. In each sample, three drops ( $2 \mu \mathrm{l}$ each) of dilution were separately placed on a clean slide and covered with $12 \mathrm{~mm}$ round cover slips. A hundred sperm cells were counted in each of the three drops to determine the percentage of sperm viability. The first 100 sperm encountered were scored live or dead based on color. This was repeated on two additional independent aliquots; the high and low values were dropped. The middle value was used as the percentage of sperm viability for statistical analysis.

\subsection{Gene expression in queen exposed to sublethal dose of amitraz}

Mated honeybee queens from a single queen breeder were randomly divided into two groups of 18 and queens were treated with either $2.5 \mathrm{ppm}$ of amitraz or methanol (control group). The application of amitraz to honeybee queens was as described above. Then, queens were placed into wooden Benton cages with five attendant bees and kept at $30 \pm$ $2{ }^{\circ} \mathrm{C}$. After $24 \mathrm{~h}$ post-treatment, nine queens from each group were collected and immediately frozen in dry ice mixed with ethanol and stored at $-80{ }^{\circ} \mathrm{C}$ for subsequent total RNA extraction.

\subsubsection{RNA extraction and cDNA synthesis}

Total RNA was isolated from individual queen abdomen using Trizol reagent (Invitrogen, Carlsbad, CA) according the manufacturer's instructions. Of total RNA, $1.5 \mu \mathrm{g}$ was used for DNA elimination using DNAse I (Invitrogen). Reaction mixture consisted of 10 U DNAse I in appropriate buffer, 20 U RNAseout (Invitrogen), poly dT(12-18), random heptamer oligonucleotides, and $2 \mathrm{mM}$ dNTP in an $11-\mu \mathrm{l}$ reaction. The reaction was run at $37^{\circ} \mathrm{C}$ for $1 \mathrm{~h}$ followed by $75^{\circ} \mathrm{C}$ for $10 \mathrm{~min}$. Then, first-stand cDNA was synthesized by using Superscript II Reverse Transcriptase (Invitrogen) following to manufacturer's protocol. The cDNA was diluted 1:5 in nuclease free water $(\sim 100 \mathrm{ng} / \mu \mathrm{l})$. 


\subsubsection{Quantitative real-time PCR}

The expression of 17 different target genes involved in detoxification, immunity, memory, antioxidant, and development was determined using qPCR. The reaction was carried out in 96well plates using a Bio-Rad Icycler (Bio-Rad Crop., Hercules, CA.). A 100-ng/ $\mu$ l cDNA template was used for the reaction. The qPCR was performed using $1 \times$ SsoAdvanced ${ }^{\mathrm{TM}}$ SYBR ${ }^{\circledR}$ Green supermix (Bio-Rad) and $0.2 \mu \mathrm{M}$ of each primer. Primers used for amplification of the target genes are listed in Table 1 (Evans 2006;
Simone et al. 2009; Li et al. 2010). The PCR conditions were $95{ }^{\circ} \mathrm{C}$ for $30 \mathrm{~s}$ followed by 50 cycles of $95{ }^{\circ} \mathrm{C}$ for $5 \mathrm{~s}, 60{ }^{\circ} \mathrm{C}$ for $30 \mathrm{~s}$, and melt curve from 65 to $95{ }^{\circ} \mathrm{C}$ in $0.5^{\circ} \mathrm{C} / 5 \mathrm{~s}$ increments. The melt curve dissociation was analyzed to confirm each amplicon. Relative expression levels were analyzed using the $\Delta \Delta \mathrm{C}_{\mathrm{T}}$ method. Ribosomal protein subunit 5 was chosen as the reference gene and used to normalization. Threshold cycle $\left(\mathrm{C}_{\mathrm{T}}\right)$ numbers for target genes were subtracted from the reference gene for each sample $\left(\Delta \mathrm{C}_{\mathrm{T}}\right)$. Then, the $\Delta \Delta \mathrm{C}_{\mathrm{T}}$ in each sample was calculated by subtracting $\Delta \mathrm{C}_{\mathrm{T}}$ of the sample from minimum

Table 1. Oligonucleotide sequences of qPCR used in this study

\begin{tabular}{|c|c|c|c|}
\hline Gene & Forward sequence $\left(5^{\prime}-3^{\prime}\right)$ & Reverse sequence $\left(5^{\prime}-3^{\prime}\right)$ & Reference \\
\hline Ribosomal protein S5 & $\begin{array}{l}\text { AATTATTTGGTCGC } \\
\text { TGGAATTG }\end{array}$ & $\begin{array}{l}\text { TAACGTCCAGCAGA } \\
\text { ATGTGGTA }\end{array}$ & Evans 2006 \\
\hline Cytochrome P450 306A1 & $\begin{array}{l}\text { CGTCGATGGGAAGG } \\
\text { ATAAAA }\end{array}$ & $\begin{array}{l}\text { TCGGTGAAATATCC } \\
\text { CGATTC }\end{array}$ & \\
\hline Cytochrome P450 4G11 & $\begin{array}{l}\text { CAAAATGGTGTTCT } \\
\text { CCTTACCG }\end{array}$ & $\begin{array}{l}\text { ATGGCAACCCATCA } \\
\text { CTGC }\end{array}$ & \\
\hline Cytochrome P450 6AS14 & $\begin{array}{l}\text { TGAAACTCATGACC } \\
\text { GAGACG }\end{array}$ & $\begin{array}{l}\text { AAAATTTGGGCCGC } \\
\text { TAATAAA }\end{array}$ & \\
\hline Glutathione S-transferase S3 & $\begin{array}{l}\text { TGCATATGCTGGCA } \\
\text { TTGATT }\end{array}$ & $\begin{array}{l}\text { TCCTCGCCAAGTAT } \\
\text { CTTGCT }\end{array}$ & \\
\hline cAMP-dependent protein kinase 1 & $\begin{array}{l}\text { TCCATTTTTGGTCT } \\
\text { CCTTGC }\end{array}$ & $\begin{array}{l}\text { GTAAAAGCGCGAAT } \\
\text { GTGGTT }\end{array}$ & \\
\hline $\begin{array}{l}\text { cAMP-dependent protein kinase type } 1 \\
\text { regulatory subunit }\end{array}$ & $\begin{array}{l}\text { GAAGCAATTATTCG } \\
\text { GCAAGG }\end{array}$ & $\begin{array}{l}\text { TCACCGAAACTTCC } \\
\text { ACCTTC }\end{array}$ & \\
\hline Catalase & $\begin{array}{l}\text { GTCTTGGCCCAAAC } \\
\text { AATCTG }\end{array}$ & $\begin{array}{l}\text { CATTCTCTAGGCCC } \\
\text { ACCAAA }\end{array}$ & \\
\hline Superoxide dismutase & $\begin{array}{l}\text { TACCAATTCCGTGA } \\
\text { AGGTCA }\end{array}$ & $\begin{array}{l}\text { TTGAAATGTGCACC } \\
\text { AGCACT }\end{array}$ & \\
\hline Abaecin & $\begin{array}{l}\text { CAGCATTCGCATAC } \\
\text { GTACCA }\end{array}$ & $\begin{array}{l}\text { GACCAGGAAACGTT } \\
\text { GGAAAC }\end{array}$ & \\
\hline Apidaecin type 22 & $\begin{array}{l}\text { TTTTGCCTTAGCAA } \\
\text { TTCTTGTTG }\end{array}$ & $\begin{array}{l}\text { GTAGGTCGAGTAGG } \\
\text { CGGATCT }\end{array}$ & \\
\hline Defensin & $\begin{array}{l}\text { TGCGCTGCTAACTG } \\
\text { TCTCAG }\end{array}$ & $\begin{array}{l}\text { AATGGCACTTAACC } \\
\text { GAAACG }\end{array}$ & \\
\hline Hymenoptaecin & $\begin{array}{l}\text { CTCTTCTGTGCCGT } \\
\text { TGCATA }\end{array}$ & $\begin{array}{l}\text { GCGTCTCCTGTCAT } \\
\text { TCCATT }\end{array}$ & \\
\hline NimC1, eater-like & $\begin{array}{l}\text { CATTTGCCAACCTG } \\
\text { TTTGT }\end{array}$ & $\begin{array}{l}\text { ATCCATTGGTGCAA } \\
\text { TTTGG }\end{array}$ & \\
\hline Serine protease & $\begin{array}{l}\text { GTTTGGTCGACGGA } \\
\text { AGAAAA }\end{array}$ & $\begin{array}{l}\text { CCGTCGACTCGAAA } \\
\text { TCGTAT }\end{array}$ & \\
\hline Hexamerin $70 b$ & $\begin{array}{l}\text { AACTCGCTCAACTT } \\
\text { TCCACAA }\end{array}$ & $\begin{array}{l}\text { GGCTCACATAACTA } \\
\text { ACCTCACC }\end{array}$ & \\
\hline Thioredoxin peroxidase 1 & $\begin{array}{l}\text { CAGCATCTACTGAT } \\
\text { TCTCACTTC }\end{array}$ & $\begin{array}{l}\text { AGACCACGAAATGG } \\
\text { AACTCC }\end{array}$ & Li et al. 2010 \\
\hline Vitellogenin & $\begin{array}{l}\text { AGTTCCGACCGACG } \\
\text { ACGA }\end{array}$ & $\begin{array}{l}\text { TTCCCTCCCACGGA } \\
\text { GTCC }\end{array}$ & $\begin{array}{l}\text { Simone et al. } \\
2009\end{array}$ \\
\hline
\end{tabular}


value $\Delta \mathrm{C}_{\mathrm{T}}$ of the group. According to the efficiency of primer, a low transcript level ( $\sim 10$ copies) was detected at 42 cycles. Thus, the $\mathrm{C}_{\mathrm{T}}$ numbers of 42 cycles were assigned for the sample that the threshold cycle showed after the cycle 42 .

\subsection{Amitraz field study}

To obtain a set of mated queens for colony level testing, 200 mature queen cells ( 9 days post grafting of larvae into queen cups) were added to small queenless colonies (nuclei colonies) containing five frames of immature brood and honeybees. Colonies were held in the same apiary near Turlock, CA and newly emerged virgin queens allowed 6 weeks to mate and become established prior to relocating the colonies to North Dakota. Thus, all queens mated with drones from the same geographic area in California. Colonies were moved to North Dakota and placed into larger 10-frame Langstroth equipment in May of 2014. On June 2, 2014, the 200 colonies were inspected and queens located and paint-marked (Testers $\left.{ }^{\circledR}\right)$ in 160 colonies of equal strength. Colonies were rated for frames covered in adult bees, estimated to the nearest 0.5 frames similar to the Liebefeld method (Imdorf et al. 1987) and brood pattern was rated by holding a 100-cell template over 4 areas containing sealed brood (vanEngelsdorp et al. 2009). Colonies were rated and queens marked, within sets of five, each colony was number tagged and randomly assigned to one of five treatment groups. Three colony-level amitraz treatments were applied: (1) two strips of Apivar® per label instructions, (2) amitraz in canola oil at ca. $10 \%$ a.i. amitraz on a paper towel, and (3) amitraz in semi-solid vegetable oil (Crisco $\AA$ ) at ca. $10 \%$ a.i. amitraz. These two application methods were used to mimic the application methods employed by some beekeepers. Imidacloprid treatment to queens was considered as a positive control at the dose (0.02 ppm) which had killed on average 50\% of sperm in treated queens in the laboratory (Chaimanee et al. 2016). Each imidacloprid treated queens was captured and held while a $2-\mu 1$ dose was applied to her abdomen and then she was released back into the colony. Negative control queens received neither chemical nor solvent treatment, but all queens were handled during paint marking and then released. Following assessment and treatment of colonies and queens, colonies were relocated 1 week later to four apiaries with 40 colonies per apiary and all treatments equally represented in each apiary $(n=8$ colonies/treatment and apiary). Colonies were managed by the beekeeper from June to September for honey production and no additional mite treatments were made.

In September of 2014, all colonies were reassessed for bee strength and brood pattern as above and each queen located and a determination made if she retained the original paint marked or had been superceded (no paint mark), was missing (queenless) or the colony had died. When queens were found to have original paint marks, 15 from each treatment group were captured and placed in new wooden queen cages with 4-6 attendant bees for transportation back to Beltsville MD for live/ dead sperm viability assessments. Queens were transported as carry-on luggage on the airplane, dissected alive and live/dead sperm assessments made in Beltsville 2-4 days after removal from colonies in North Dakota.

\subsection{Statistical analysis}

All statistical tests were performed using the software JMP version 11.0 for (SAS Institute Inc.). Differences of the mean transcript levels between the pesticide treatment group and untreated control group, the parametric unpaired $t$ test was used to analyze if the data fitted a normal distribution. However, the non-parametric Wilcoxon's test was applied when the data sets were not normally distributed. The sperm viability and the number of frames covered with adult bees were analyzed by ANOVA if the data conformed to a normal distribution. The non-parametric Steel-Dwass test was used when the data sets were not normally distributed. Chi-square test was applied to analyze the queen status after pesticide treatment. The difference was determined statistically significant at $p \leq 0.05$. 


\section{RESULTS}

\subsection{Effect of sublethal doses of amitraz on sperm viability in honey bee queens}

No mortality of honeybee queens was observed during experiment. The live/dead sperm counts showed that sperm viability stored in the queens' spermathecae was not significantly affected by a broad range of concentrations of amitraz after 7 days of exposure under laboratory condition (ANOVA, $p>0.05$ ) (Figure 1). The percent of sperm viability ranged from 26 to $42 \%$. Also, the spermatozoa viability of control queens was about $42 \%$.

\subsection{Gene expression in honeybee queens exposed to amitraz}

The expression of genes differed in queens after amitraz treatment. Three of four detoxification enzyme genes tested (CYP4G11, CYP6AS14, and GSTs 3 ) were downregulated $24 \mathrm{~h}$ after exposure to amitraz (Figure 2a). Only transcript levels of CYP306A1 were elevated by amitraz but the differences were not significant. Transcript levels of genes related to cAMP-dependent protein kinase, $P K A-C 1$ and $P K A-R 1$, were significantly downregulated in amitraz-treated queens ( $t$ test, $p=0.0206$ for $P K A-C 1$ and $p=0.0087$ for $P K A-R 1$ ) (Figure 2a). Transcript levels of the antioxidant enzyme genes, catalase, superoxide dismutase, and thioredoxin peroxidase were significantly suppressed (1.6-3.8 fold changes) in honey bee queens treated with amitraz after $24 \mathrm{~h}(t$ test, $p=0.0026, p=0.0037$ and $p<0.0001$, respectively) (Figure 2b). Immunity-related genes were differentially expressed in amitraz-treated queens. Queens exposed to amitraz had a trend toward higher expression of abaecin, defensin, and hymenoptaecin than those exposed to methanol (control group), but the differences were not significant. However, expression levels of serine protease 8 (2.89-fold) were significantly decreased in amitraz-treated queens ( $t$ test, $p=0.0011$ ). Expression of eater also showed a downregulated trend after amitraz treatment (Figure 2c). Amitraz significantly affected development-related genes in queens. Transcript levels of hexamerin $70 \mathrm{~b}$ (3.19-fold) and vitellogenin (1.79-fold) were significantly downregulated in amitraz-treated queens ( $t$ test, $p<0.0001$ and $p=0.0004$, respectively) (Figure $2 \mathrm{~d}$ ).

\subsection{Field measurements: colony strength, brood pattern, queen status, and sperm viability in queens}

Frames of bees were not different among the treatment groups before the treatments were applied, with colonies averaging 4-5 frames of bees each. Three months after treatment, most colonies were larger with 13-14 frames of bees (Figure 3a). Dead colonies were observed in the treatment groups, one colony from each amitraz treatment and two colonies from imidacloprid treatment (Table 2). Amitraz and imidacloprid had no negative effects on brood pattern (Figure 3b). Queen status was not significantly affected by chemical treatment (chi-square, $p>0.05$ ). The queen survival rate was $56-78 \%$ after 3 months of treatment (Table 2). Queens were replaced in the imidacloprid treatment group (11 queens superceded) more than amitraz treatments (4-5 queens superceded) and control group (8 queens superceded), but the supercedure rates did not differ significantly.

Amitraz and imidacloprid did not have a negative effect on sperm viability in queens under field conditions over a 3-month period (Steel-Dwass, $p>0.05$ ) (Figure 4). The percent of sperm viability in surviving queens ranged from 63 to $80 \%$.

\section{DISCUSSION}

Poor queen health has been proposed to be an important cause for colony losses (vanEngelsdorp et al. 2013; Pettis et al. 2016). Several factors have been suggested as contributing causes including chemical exposure and the stressful conditions that queen are exposed to during shipment (Sandrock et al. 2014; Pettis et al. 2016). This work focused on the effects of sublethal doses of amitraz on honeybee queen supercedure, sperm viability, and some physiological defense mechanisms of queens. The experiments were performed under both laboratory and field conditions. Here, the expressions of genes related to detoxification, immunity, antioxidative enzymes, 


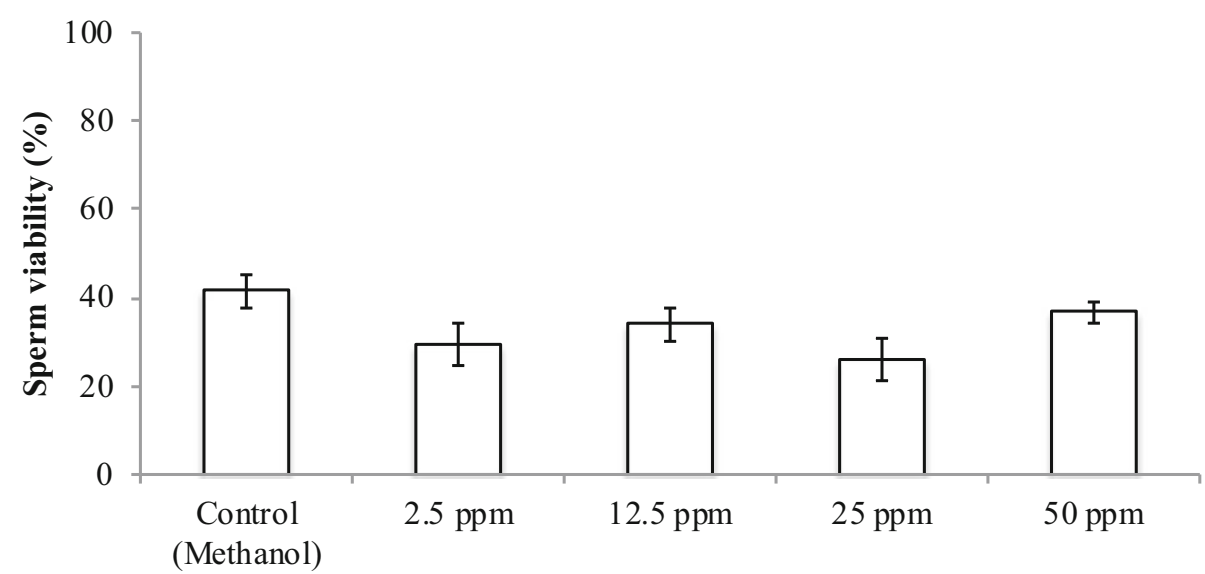

Amitraz treatment

Figure 1. The viability of spermatozoa stored in spermatheca of honey bee queens 7 days after exposure to sublethal doses of amitraz $(2.5,12.5,25$, and $50 \mathrm{ppm})$ under laboratory conditions (ANOVA, $p<0.05$ ).

and development in queens were investigated after $24 \mathrm{~h}$ of amitraz exposure. Gene expression is expected to trigger immediately after expose to xenobiotics therefore at $24 \mathrm{~h}$ of amitraz exposure was chosen for investigation. Our results demonstrated that CYP306A1, CYP4A11, CYP6AS14, and $G S T s 3$ were not significantly affected by sublethal dose of amitraz at $24 \mathrm{~h}$ of exposure indicating that they may not be immediately involved in detoxification of amitraz in honeybee queens. We also propose that GSTs may not be directly involved in amitraz detoxification and/or it could be that more time is needed to induce GSTs expression. The significant downregulation of $P K A-C 1$ and $P K A-R 1$ demonstrated that amitraz suppresses the expression of these memory-related genes. This result suggests that amitraz could impair the learning and memory processes of honey bee queens. The cAMP and cAMP-dependent protein kinase are keys in the induction of long-term memory formation in honeybee workers (Fiala et al. 1999; Müller 2000). More research is needed to explore memory related change that might be induced in queen bees.

The antioxidant enzymes, catalase, superoxide dismutase, and thioredoxin peroxidase were also measured. Honey bee queens showed highly significant downregulation of catalase, superoxide dismutase, and thioredoxin peroxidase after amitraz exposure. We demonstrate that amitraz impairs antioxidant capacity. However, these antioxidant enzymes are known to act directly to remove the reactive oxygen species (ROS) from cell damage (Corona and Robinson 2006). Thus, it might have been predicted that amitraz would upregulate these genes. The reverse was true under the conditions of our experiment.

Our results demonstrated that amitraz slightly induced abaecin, defensin, and hymenoptaecin. In contrast, eater and serine protease 8 were suppressed, but only serine protease 8 showed significant differences compared to control queens. Serine protease is involved in innate immunity and phagocytosis (Zou et al. 2006; Vannette et al. 2015). The current research supports earlier studies that demonstrated insecticide exposure suppresses immune response in honeybees. Negative effects of pesticides on honeybee immunity can lead to increases in parasite and pathogen infection (Pettis et al. 2012, 2013; Wu et al. 2012).

Lastly, hexamerin $70 b$ and vitellogenin were significantly downregulated after amitraz exposure. Hexamerins serve as storage proteins which are synthesized by the fat body and stored in hemolymph (Martins et al. 2010). Hexamerins are essential proteins to support metamorphosis and development. Adult honeybee queens may not need to store hexamerins because they continually get proteinenriched diet from worker bees (Martins et al. 2010). However, hexamerins also act as juvenile 
(a) Detoxification enzyme and cAMP-dependent protein kinase genes

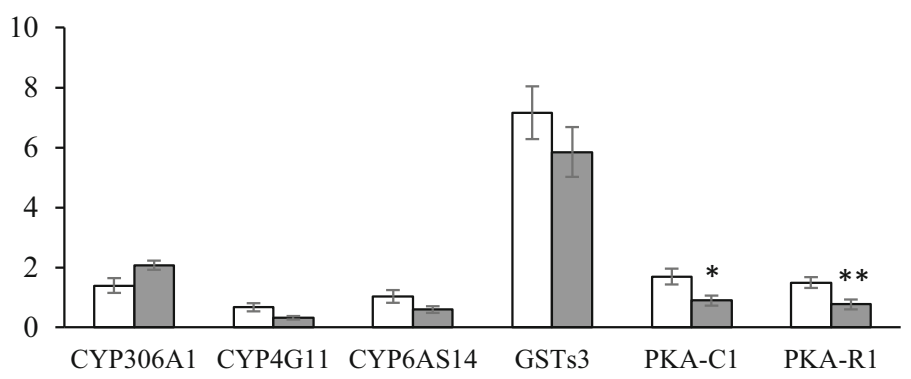

(b) Antioxidant enzyme genes

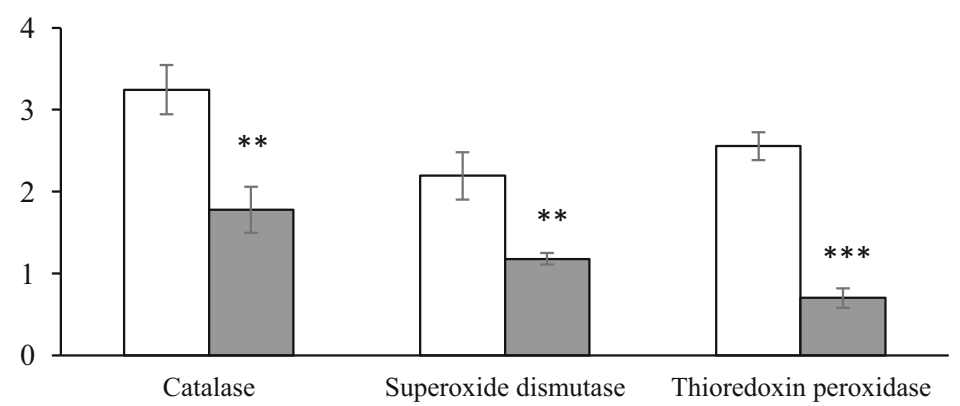

(c) Immunity genes

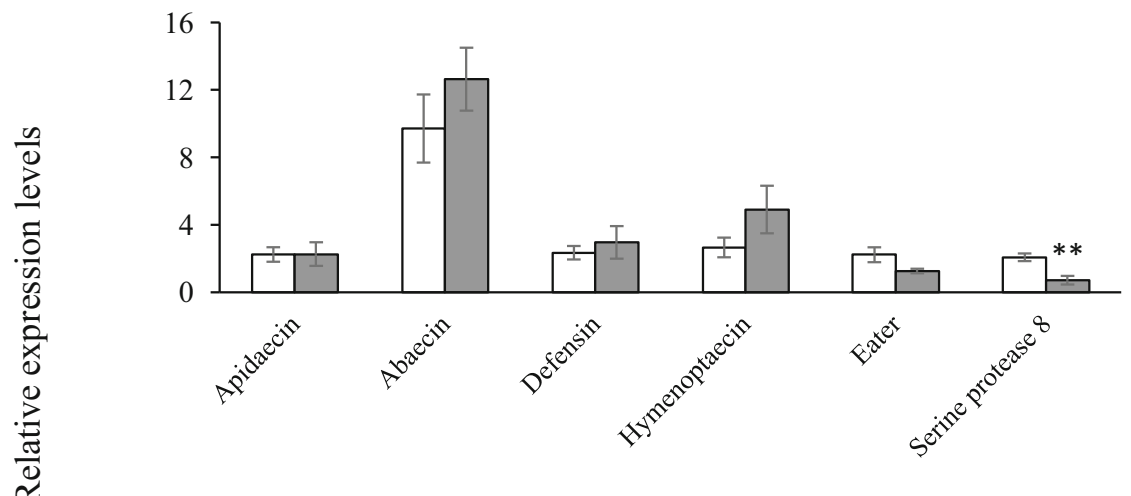

(d) Development genes

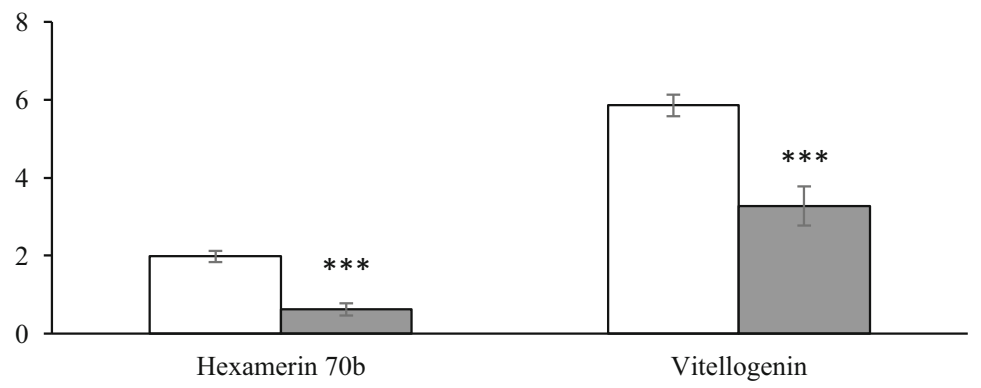


Figure 2.Expression profiles of genes related to detoxification enzymes and cAMP-dependent protein kinase (a), antioxidative enzymes (b), immunity (c), and development (d) in honeybee queens $24 \mathrm{~h}$ after exposure to amitraz at $2.5 \mathrm{ppm}$. Asterisks indicate significant differences, $* p<0.05, * * p<0.01$, and $* * * p<0.001$ ( $t$ test and Wilcoxon's test).

hormone binding proteins, regulating the juvenile hormone levels. Thus, the suppression of hexamerin may indirectly affect growth, reproduction, and longevity of honeybee queens. Also, transcript levels of vitellogenin were decreased by amitraz exposure, indicating that amitraz has an influence on ovary development and reproduction of queens. Vitellogenin and juvenile hormone have a positive correlation. Taking these together, our results demonstrated that amitraz may have direct and indirect negative impacts on development and reproduction in honeybee queens but more detailed studies are called for.

Our results suggest sublethal exposure to amitraz at the concentration of $2.5-50 \mathrm{ppm}$ does not affect the viability of spermatozoa stored in spermatheca of queens under laboratory conditions. Even given the low viability in the control queens, amitraz applied at a broad dose range and

(a)

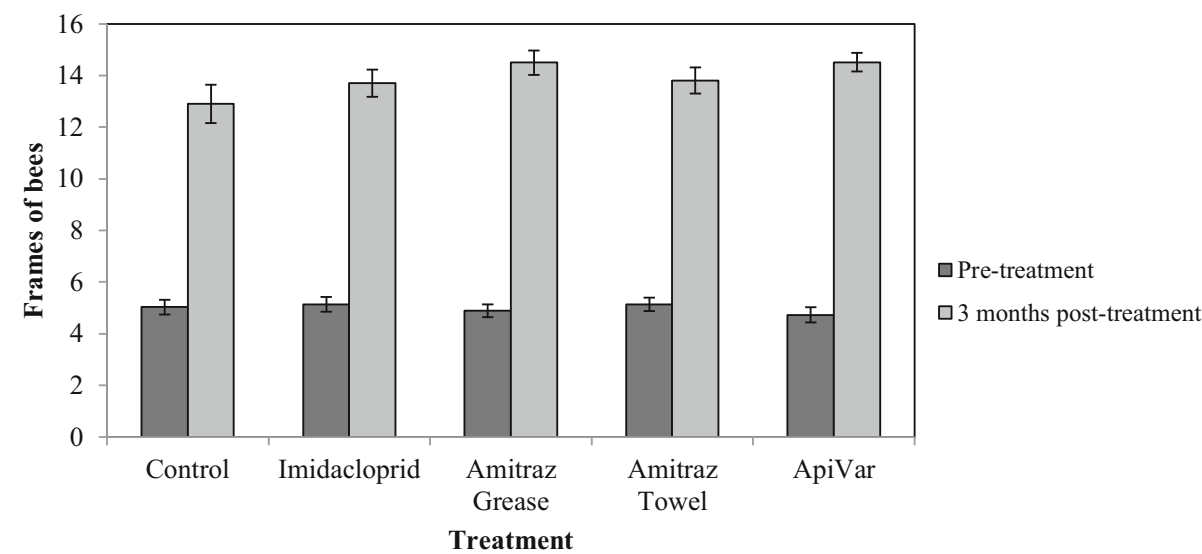

(b)

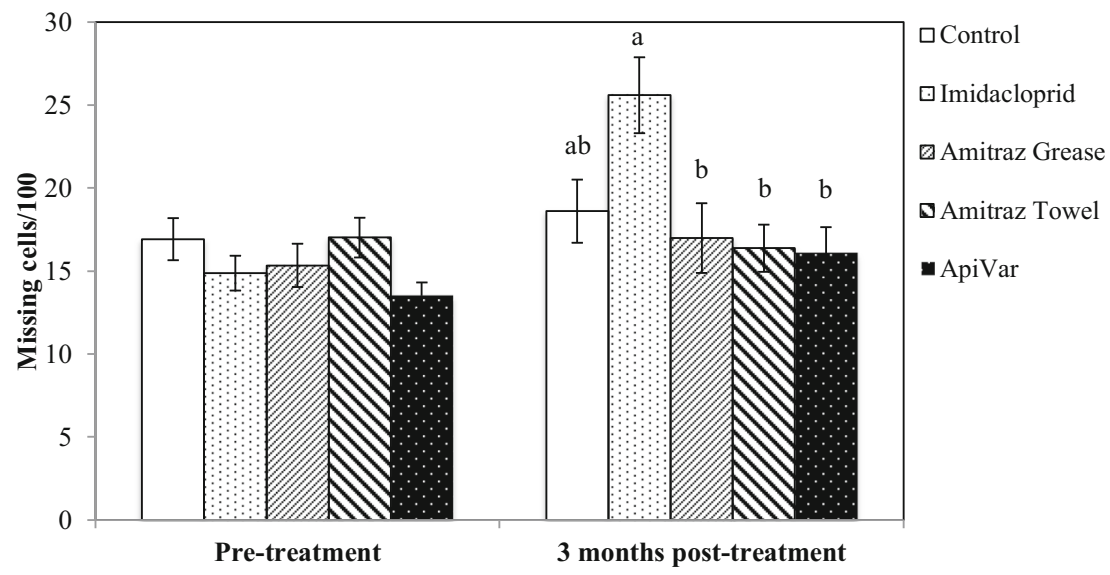

Figure 3. Frames of bees (a) and brood patterns (b) for honey bee colonies after exposure to three different amitraz treatments and imidacloprid pre- and post- ( 3 months) pesticide application. Vertical bars with different letters show statistically significant differences (Steel-Dwass test, $p<0.05$ ). 
Table 2. Queen status for honey bee colonies ( $n=32 /$ treatment) 3 months after different amitraz and imidacloprid treatments (no significant difference, chi-square test, $p>0.05$ )

\begin{tabular}{lccccc}
\hline Treatment & \multicolumn{3}{l}{ Number of queen $(n=32)$} & & \\
\cline { 2 - 6 } & Original queen & New queen & Queen less & Dead queen & \% survival after 3 months \\
\hline Control & 22 & 8 & 2 & 0 & 68.75 \\
Imidacloprid & 18 & 11 & 1 & 2 & 56.25 \\
Amitraz grease & 24 & 5 & 2 & 1 & 75.00 \\
Amitraz towel & 24 & 4 & 3 & 1 & 75.00 \\
ApiVar & 25 & 4 & 2 & 1 & 78.12 \\
\hline
\end{tabular}

directly to the queen's abdomen failed to show impact on stored sperm. The low control viability we assume may be the results of a temperature extreme during shipment or just a poor group of queens (Pettis et al. 2016). Queens may be exposed to temperature spikes $\left(8-40{ }^{\circ} \mathrm{C}\right)$ during shipment, and these spikes can kill $50 \%$ or more of spermatozoa stored in spermatheca of queens; unfortunately, we did not follow the shipping temperatures on these queens (Pettis et al. 2016).

Although there were no differences in sperm viability between queens exposed to sublethal doses of amitraz in the laboratory, we wished to test the effect of amitraz on sperm viability in queens heading colonies following three application methods of amitraz that mimicked the application methods employed by some beekeepers. Treating colonies with amitraz using three application techniques indicated that under these field conditions, no adverse effects were seen on queen loss or sperm viability over a 3month period. The use of imidacloprid as a positive control on queens in this study did not result in significant queen loss and surviving queens had equal of greater sperm viability compared to controls. There was a trend toward higher queen losses in the positive controls and the use of a higher colony replicate number may have elicidated this effect if it were indeed real. Although laboratory data indicated that a $50 \%$ reduction in sperm viability after 7 days of $0.02 \mathrm{ppm}$ imidacloprid application (Chaimanee et al. 2016);

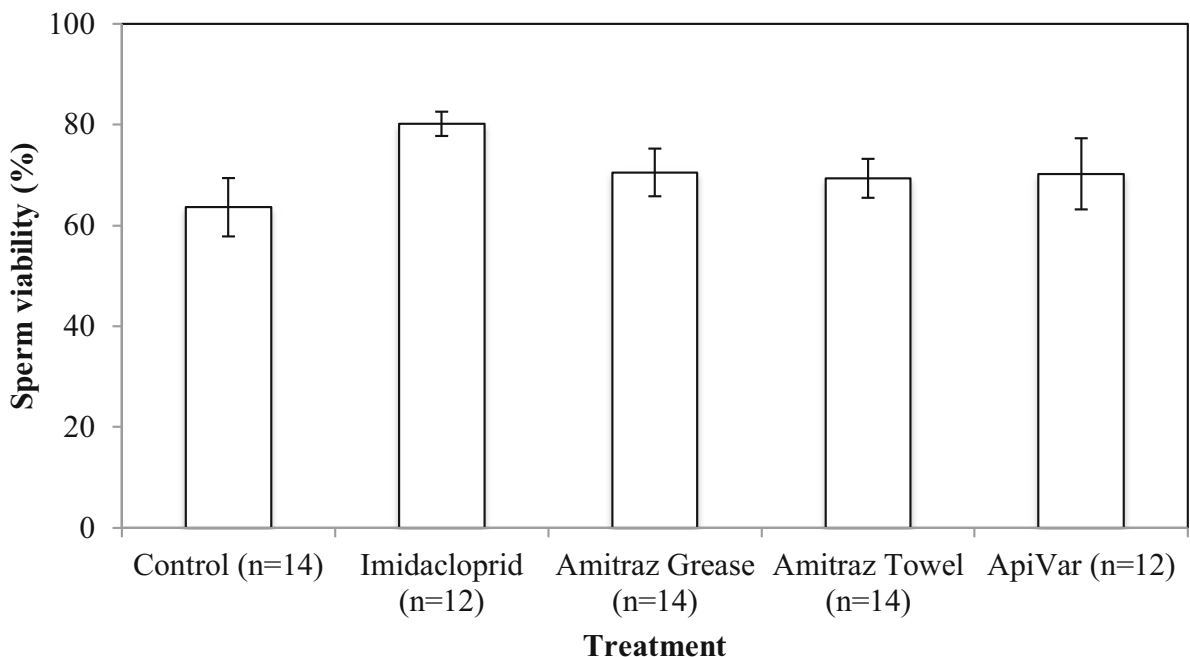

Figure 4. The viability of spermatozoa stored in spermatheca of honey bee queens 3 months after exposure to amitraz and imidacloprid under field conditions (Steel-Dwass test, $p<0.05$ ). 
however, the same amount of imidacloprid appeared to increased sperm viability in the field study. Perhaps the queens that were most affected by imidacloprid were superceded, and this leads to the apparent increase in sperm viability in those queens that survived (i.e., the poorer queens were superceded). Brood pattern may be an indicator of queen quality (vanEngelsdorp et al. 2009; Pettis et al. 2016), but no apparent changes were observed in brood pattern in the current study that could be linked to queen quality. Amitraz treatment for mites under realistic commercial beekeeping conditions did neither result in queen loss nor reduced sperm viability. Beekeepers can feel reasonably safe with this miticide, but adverse queen effects have been seen with another miticide, coumaphos (Collins et al. 2004; Pettis et al. 2004), and thus caution should be used in the timing and number of application of mitecontrol products. Taken together, this research indicated that amitraz offers a reasonably safe mite treatment with few direct adverse effects on queen health.

\section{ACKNOWLEDGMENTS}

We thank Zac Browning, the staff of Browning Honey Company, Nathan Rice, and Katie Joselow for their invaluable help in conducting the experiments; Bart Smith for assistance with honey bee queens; and Dawn Lopez for providing technical and molecular assistance.

\section{AUTHORS' CONTRIBUTION}

VC and JSP conceived this research, designed experiments, performed the experiments, data analysis and wrote the paper. All authors read and approved the final manuscript.

\section{FUNDING INFORMATION}

Funding was provided in part from the USDAARS Areawide Program to improve colony health.

\section{COMPLIANCE WITH ETHICAL STANDARDS}

Conflict of interest The authors declare that they have no conflict of interest.
Expression des gènes, viabilité des spermatozoïdes et perte de reine (Apis mellifera) à la suite d'une exposition à un pesticide en laboratoire et sur le terrain

Apis mellifera / reines / viabilité des spermatozoïdes / amitraz / expression génétique / conditions de terrain

Genexpression, Spermienverfügbarkeit und Königinnenverluste (Apis mellifera) als Folge einer Pestizidexposition unter Labor- und Feldbedingungen

Apis mellifera / Königin / Spermienlebensfähigkeit / Amitraz / Genexpression / Feldbedingungen

\section{REFERENCES}

Antúnez, K., Martín-Hernández, R., Prieto, L., Meana, A., Zunino, P., Higes, M. (2009) Immune suppression in the honey bee (Apis mellifera) following infection by Nosema ceranae (Microsporidia). Environ. Microbiol. 11, 2284-2290

Antúnez, K., Invernizzi, C., Mendoza, Y., vanEngelsdorp, D., Zunino, P. (2017) Honeybee colony losses in Uruguay during 2013-2014. Apidologie 48, 364-370

Berenbaum, M.R. (2002) Postgenomic chemical ecology: from genetic code to ecological interactions. J. Chem. Ecol. 28, 873-896

Brandt, A., Grikscheit, K., Siede, R., Grosse, R., Meixner, M.D., Büchler, R. (2017) Immunosuppression in honeybee queens by the neonicotinoids thiacloprid and clothianidin. Sci. Rep. 7, 4673

Chaimanee, V., Evans, J.D., Chen, Y., Jackson, C., Pettis, J.S. (2016) Sperm viability and gene expression in honey bee queens (Apis mellifera) following exposure to the neonicotinoid insecticide imidacloprid and the organophosphate acaricide coumaphos. J. Insect Physiol. $89,1-8$

Claudianos, C., Ranson, H., Johnson, R.M., Biswas, S., Schuler, M.A., Berenbaum, M.R., Feyereisen, R., Oakeshott, J.G. (2006) A deficit of detoxification enzymes: pesticide sensitivity and environmental response in the honeybee. Insect Mol. Biol. 15, 615-636

Collins, A.M., Pettis, J.S., Wilbanks, R., Feldlaufer, M.F. (2004) Performance of honey bee, Apis mellifera, queens reared in beeswax cells impregnated with coumaphos. J. Apic. Res. 43, 128-134

Cornman, R.S., Tarpy, D.R., Chen, Y., Jeffreys, L., Lopez, D., Pettis, J.S., vanEngelsdorp, D., Evans, J.D. (2012) Pathogen webs in collapsing honey bee colonies. PLoS One 7, e43562 
Corona, M., Robinson, G.E. (2006) Genes of the antioxidant system of the honey bee: annotation and phylogeny. Insect Mol. Biol. 15, 687-701

Dahlgren, L., Johnson, R.M., Siegfried, B.D., Ellis, M.D. (2012) Comparative toxicity of acaricides to honey bee (Hymenoptera: Apidae) workers and queens. J. Econ. Entomol. 105, 1895-1902

Desneux, N., Decourtye, A., Delpuech, J-M. (2007) The sublethal effects of pesticides on beneficial arthropods. Annu. Rev. Entomol. 52, 81-106

Di Prisco, G., Cavaliere, V., Annoscia, D., Varricchio, P., Caprio, E., Nazzi, F., Gargiulo, G., Pennacchio, F. (2013) Neonicotinoid clothianidin adversely affects insect immunity and promotes replication of a viral pathogen in honey bees. Proc. Natl. Acad. Sci. U S A 110, 18466-18471

Dively, G.P., Embrey, M.S., Kamel, A., Hawthorne, D.J., Pettis, P.S. (2015) Assessment of chronic sublethal effects of imidacloprid on honey bee colony health. PLoS One 10, e0118748

Elzen, P.J., Westervelt, D. (2002) Dectection of coumaphos resistance in Varroa destructor in Florida. Am. Bee J. 142, 291-292

Elzen, P.J., Eischen, F.A., Baxter, J.B., Pettis, J., Elzen, G.W., Wilson, W.T. (1998) Fluvalinate resistance in Varroa jacobsoni from several geographic locations. Am. Bee J. 138, 674-676

Enayati, A.A., Ranson, H., Hemingway, J. (2005) Insect glutathione transferases and insecticide resistance. Insect Mol. Biol. 14, 3-8

Evans, J.D. (2006) Beepath: an ordered quantitative-PCR array for exploring honey bee immunity and disease. J. Invertebr. Pathol. 93, 135-139

Evans, P.D., Gee, J.D. (1980) Action of formamidine pesticides on octopamine receptors. Nature 28, 60-62

Evans, J.D., Schwarz, R.S. (2011) Bees brought to their knees: microbes affecting honey bee health. Trends Microbiol. 19, 614-620

Feyereisen, R. (2005) Insect cytochrome P450. In Comprehensive Molecular Insect Science-Biochemistry and Molecular Biology, Vol. 4 (Gilbert LI, Latrou K, Gill SS, eds). Pp 1-77. Elsevier, Oxford

Fiala, A., Müller, U., Menzel, R. (1999) Reversible downregulation of protein kinase A during olfactory learning using antisense technique impairs long-term memory formation in the honeybee, Apis mellifera. J. Nerosci. 19, 10125-10134

Garrido, P.M., Antúnez, K., Martín, M., Porrini, M.P., Zunino, P., Eguaras, M.J. (2013) Immune-related gene expression in nurse honey bees (Apis mellifera) exposed to synthetic acaricides. J. Insect Physiol. 59, 113-119

Hu, Y.T., Wu, T.C., Yang, E.C., Wu, P.C., Lin, P.T., Wu, Y.L. (2017) Regulation of genes related to immune signaling and detoxification in Apis mellifera by an inhibitor of histone deacetylation. Sci. Rep. 7, 41255

Imdorf, A., Buehlmann, G., Gerig, L., Kilchenmann, V., Wille, H. (1987) A Test of the method of estimation of brood areas and number of worker bees in free-flying colonies. Apidologie 18, 137-146

Johnson, R.M., Wen, Z., Schuler, M.A., Berenbaum, M.R. (2006) Mediation of pyrethroid insecticide toxicity to honey bees (Hymenoptera: Apidae) by cytochrome P450 monoxygenases. J. Econ. Entomol 99, 10461050

Johnson, R.M., Mao, W., Pollock, H.S., Niu, G., Schuler, M.A., Berenbaum, M.R. (2012) Ecologically appropriate xenobiotics induce cytochrome P450s in Apis mellifera. PLoS One 7, e31051

Johnson, R.M., Dahlgren, L., Siegfried, B.D., Ellis, M.D. (2013) Acaricide, fungicide and drug interactions in honey bees (Apis mellifera). PLoS One 8, e54092

Ketterman, A.J., Saisawang, C., Wongsantichon, J. (2011) Insect glutathione transferases. Drug Metab. Rev. 43, 253-265

Klein, A.M., Vaissiere, B.E., Cane, J.H., Steffan-Dewenter, I., Cunningham, S.A., Kremen, C., Tscharntke, T. (2007) Importance of pollinators in changing landscapes for world crops. Proc. R. Soc. B 274, 303-313.

Korta, E., Bakkali, A., Berrueta, L.A., Gallo, B., Vicente, F., Kilchenmann, V., Bogdanov, S. (2001) Study of acaricide stability in honey, characterization of amitraz degradation products in honey and beeswax. J. Agric. Food Chem. 49, 5835-5842

Li, X., Schuler, M.A., Berenbaum, M.R. (2007) Molecular mechanisms of metabolic resistance to synthetic and natural xenobiotics. Annu. Rev. Entomol. 52, 231-253

Li, J., Wu, J., Rundassa, D.B., Song, F., Zheng, A., Fang, Y. (2010) Differential protein expression in honeybee (Apis mellifera L.) larvae: underlying caste differentiation. PLoS One 5, e13455

Lumjuan, N., Rajatileka, S., Changsom, D., Wicheer, J., Leelapat, P., Prapanthadara, L.A., Somboon, P., Lycett, G., Ranson, H. (2011) The role of the Aedes aegypti Epsilon glutathione transferases in conferring resistance to DDT and pyrethroid insecticides. Insect Biochem. Mol. Biol. 41, 203-209

Mao, W., Schuler, M.A., Berenbaum, M.R. (2011) CYP9Q-mediated detoxification of acaricides in the honey bee (Apis mellifera). Proc. Natl. Acad. Sci. $108,12657-12662$

Martins, J.R., Nunes, F.M.F., Cristino, A.S., Simoes, Z.L.P., Bitondi, M.M.G. (2010) The four hexamerin genes in the honey bee: structure, molecular evolution and function deduced from expression patterns in queens, workers and drones. Mol. Biol. 11, 23

Moritz, R.F.A. (1984) The effect of different diluents on insemination success in the honeybee using mixed semen. J. Apic. Res. 23, 164-167

Müller, U. (2000) Prolonged activation of cAMPDependent protein kinase during conditions induces long-term memory in honeybees. Neuron. 27, 159168

Mullin, C.A., Frazier, M., Frazier, J.L., Ashcraft, S., Simonds R, vanEngelsdorp, D., Pettis, S.P. (2010) High levels of miticides and agrochemicals in North 
American apiaries: implications for honey bee health. PLoS One 5, e9754

Pettis, J.S. (2004) A scientific note on Varroa destructor resistance to coumaphos in the United States. Apidologie 35, 91-92

Pettis, J.S., Collins, A.M., Wilbanks, R., Feldlaufer, M.F. (2004) Effects of coumaphos on queen rearing in the honey bee, Apis mellifera. Apidologie 35, 605-610

Pettis, J.S., vanEngelsdorp, D., Johnson, J., Dively, G. (2012) Pesticide exposure in honey bees results in increased levels of the gut pathogen Nosema. Naturwissenschaften 99, 153-158

Pettis, J.S., Lichtenberg, E.M., Andree, M., Stitzinger, J., Rose, R.,vanEngelsdorp, D. (2013) Crop pollination exposes honey bees to pesticides which alters their susceptibility to the gut pathogen $N$. ceranae. PLoS One 8, e70182

Pettis, J.S., Rice, N, Joselow, K., vanEngelsdorp, D., Chaimanee, V. (2016) Colony failure linked to low sperm viability in honey bee (Apis mellifera) queens and an exploration of potential causative factors. PLoS One 11, e0147220

Rangel, J., Keller, J., Tarpy, D.R. (2013) The effect of honey bee (Apis mellifera L.) queen reproductive potential on colony growth. Insects Soc. 60, 65-73

Ranson, H., Claudianos, C., Ortelli, F., Abgrall, C., Hemingway, J., Sharakhova, M.V., Unger, M.F., Collins, F.H., Feyereisen, R. (2002) Evolution of supergene families associated with insecticide resistance. Science 298, 179-181

Rinkevich, F.D., Margotta, J.W., Pittman, J.M., Danka, R.G., Tarver, M.R., Ottea, J.A., Healy, K.B. (2015) Genetics, synergists, and age affect insecticide sensitivity of the honey bee, Apis mellifera. PLoS One 8, e0139841

Rix, R.R., Cutler, G.C. (2017) Acute exposure to worstcase concentartions of amitraz does not affect honey bee learning, short-term memory, or hemolymph octopamine levels. J. Econ. Entomol. 110, 127-132

Sandrock, C., Tanadini, M., Tanadini, L.G., Fauser-Misslin, A., Potts, S.G., et al. (2014) Impact of chronic neonicotinoid exposure on honeybee colony performance and queen supersedure. PLoS One 9, e103592

Simone, M., Evans, J.D., Spivak, M. (2009) Resin collection and social immunity in honey bees. Evolution 63, 3016-3022
Straub, L., Villamar-Bouza, L., Bruckner, S., Chantawannakul, P., Gauthier, L., et al. (2016) Neonicotinoid insecticides can serve as inadvertent insect contraceptives. Proc. R. Soc. B 283, 20160506

Vandenberg, J.D., Shimanuki, H. (1990) Effect of amitraz treatments on honey bees and on the honey bee tracheal mite. Apidologie 21, 243-247

vanEngelsdorp, D., Evans, J.D., Saegerman, C., Mullin, C., Haubruge, E., Nguyen, B.K., Frazier, M., Frazier, J., Cox-Foster, D., Chen, Y., Underwood, R., Tarpy, D.R., Pettis, J.S. (2009) Colony collapse disorder: a descriptive study. PloS One 4, e6481

vanEngelsdorp, D., Tarpy, D.R., Lengerich, E.J., Pettis, J.S. (2013) Idiopathic brood disease syndrome and queen events as precursors of colony mortality in migratory beekeeping operations in eastern United States. Prev. Vet. Med. 108, 225-233

Vannette, R.L., Mohamed, A., Johnson, B.R. (2015) Forager bees (Apis mellifera) highly express immune and detoxification genes in tissues associated with nectar processing. Sci. Rep. 5, 16224

Williams, G.R., Troxler, A., Retschnig, G., Roth, K., Yanez, O., Shutler, D., Neumann, P., Gauthier, L. (2015) Neonicotinoid pesticides severely affect honey bee queens. Sci. Rep. 5, 14621

Wu, J.Y., Smart, M.D., Anelli, C.M., Sheppard, W.S. (2012) Honey bees (Apis mellifera) reared in brood combs containing high levels of pesticide residues exhibit increased susceptibility to Nosema (Microsporidia) infection. J. Invertebr. Pathol. 109, 326-329

Yan, H., Jia, H., Gao, H., Guo, H., Xu, B. (2013) Identification, genomic organization, and oxidative stress response of a sigma class glutathione S-transferase gene (AccGSTS1) in honey bee, Apis cerana cerana. Cell Stress Chaperones 18, 415-426

Zou, Z., Lopez, D.L., Kanost, M.R., Evans, J.D., Jiang, H. (2006) Comparative analysis of serine protease-related genes in the honey bee genome: possible involvement in embryonic development and innate immunity. Insect Mol. Biol. 15, 603-614

Publisher's note Springer Nature remains neutral with regard to jurisdictional claims in published maps and institutional affiliations. 